\title{
Kovách Imre
}

\section{TÁRSADALMI INTEGRÁCIÓ: A KISVÁROSI SZÍNTÉR}

DOI 10.35402/kek.2020.2.1

A kisvárosok az utóbbi évtizedekben meglehetősen elfeledett területei a társadalomtudományi kutatásoknak, annak ellenére, hogy a társadalomszerveződés, a népesedési folyamatok és a politikai, hatalmi szerkezet szempontjából is megnövekedett a jelentőségük.

A városok száma megkétszereződött 1990 és 2016 között. A kilencvenes évektől 152 község kapott városi rangot. 2016-ban 938.670 fó élt ezekben az új városokban, amelyek urbanizáltsága és központ-funkciója a legtöbb esetben erősen hiányos (Pirisi 2009; Pirisi - Trócsányi 2009), a lakosság száma nem feltétlenül indult növekedésnek a várossá minősítés következtében, de különösen a nagyvárosi agglomerációkban mégis fontos helyszínei a népesedési folyamatoknak.

A mintegy háromszáz, húszezer fô alatti régi és új kisvárosban 2,3 millióan élnek, a 20000-30000 fó közötti lakosságszámú kategóriában további félmillió fô. Együttesen ez a teljes magyarországi népesség harmada. A legutolsó két országgyűlési és a 2019-es önkormányzati választásokon tapasztalt települési polarizáció következtében a kisvárosok és a vonzáskörzetükbe tartozó falvak különös politikai jelentőséget kaptak. A NER politikai rendszerének müködése talán a kisvárosokban a leginkább tetten érhető.

A politikai/választási földrajz és a népesedési adatok mellett az utóbbi évek társadalomszerkezetre és -szerveződésre vonatkozó kutatási eredményei is arra mutatnak, hogy a magyar társadalomban egy olyan csoport nyert sajátos jegyekkel leírható arculatot, amely a kisvárosi, kistelepülési társadalmi integráció és hatalmi hálózatok kulcsszereplője.

A látens osztálymodell (BBC-modell. Savage et al 2013) magyar társadalomra alkalmazása során (Albert et al. 2017) a vidéki értelmiségként azonosított osztály társadalmi mutatói a teljes, tehát nem a helyi társadalom felső középosztályához hasonlóak. A jövedelme alacsonyabb, mint a felső középosztályé, de a vagyoni helyzetük megegyezik. Társadalmi tőkéje, kulturális fogyasztása, képzettsége, presztízse magas, kapcsolathálója a legnagyobb az összes osztály között. A munkaerőpiaci aktivitásuk és beosztásuk is a felső-középosztályéhoz hasonló. Kevés, mindössze 7 százalék köztük a budapesti, a legtöbben vidéki városokban élnek.
A társadalmi integrációval foglalkozó kutatási programjaink során 2015-ben és 2018-ban is készítettünk adatfelvételt (Kovách et al 2016, 2017; Gerő et al. 2020), amelynek egyik célja a legfontosabb integrációs csoportok azonosítása volt a magyar társadalomban. Mind a két adatfelvétel elemzése során ugyanazokat a változókat és módszert alkalmaztuk a csoportok azonosítására. A két felvétel adatelemzése során létrehozott integrációs modell csoportjainak arányai az összes csoporton belül nem összehasonlíthatóak, azonban az egyes dimenziókban mért értékeik már igen. A 2018-as modell 7 csoportja közül öt a létrehozáshoz használt dimenziók szerint erős hasonlóságot mutatott a 2015-ös csoportokkal, ezért döntöttünk úgy, hogy elnevezésük hasonló lesz.

A lokálisan integrált csoport a 2015-ös és a 2018-as integrációs modellben is határozottan és világosan azonosítható volt. A 2015-ös modellt alkotó csoportok közül a budapestiek aránya itt volt a legkisebb, és a kistelepüléseken a legmagasabb. Nagy kapcsolathálóval rendelkeznek, politikailag különösen aktívak, különösen a civil szervezetek támogatása és a helyi politika képviselőivel való együttműködés területén. Szubjektív kirekesztettség-érzésük messze átlagon alatti. A diplomások aránya a második legmagasabb, viszont a diplomás apák mutatója a legjobb.

A 2018-as integrációs modellben a lokálisan integráltak civil szervezeti tagsága a legmagasabb és a személyes részvételt igénylő, a választásokon túl is megmutatkozó politikai aktivitás is kimagasló, amihez széles kapcsolatháló társul. Háromnegyed részük kisebb településen él, Budapesten csak 6 százalékuk. A diplomások és a diplomával rendelkező apák száma átlag feletti, saját bevallott nettó jövedelmük a legmagasabb.

A kvantitatív eredmények alapján arra jutottunk, hogy a vidéki (elsősorban kisvárosi) magyar társadalomban önálló társadalmi rétegként erösödött meg a magas kulturális és anyagi tőkével, a nagyvárosi felső középrétegekkel összemérhető kulturális fogyasztással, előnyös családi hátérrel rendelkező, elsősorban a helyi politikában kivételesen aktív, a lokális társadalomban integrált réteg. Egyes elemzésekből ismertük azt, hogy a helyi 
társadalmak politikai/hatalmi integrációjában erős szerepe van a fejlesztési források projekt alapú elosztásának, a kulturális dimenziónak és az identitáspolitikának (Csurgó - Kovách 2017). A kvantitatív eredmények alapján úgy gondoltuk, hogy a kimutathatóan saját társadalmi jellemzőkkel rendelkező réteg a vidéki/kisvárosi társadalmi integráció föszereplője. Ennek a pontosabb megismerésére szerveztük meg a kisvároskutatást, amelynek eredményeit a következő esettanulmányok mutatják be. Mivel a kutatási terepnek választott hét kisváros semmiképp se reprezentálhatta a számba jöhető háromszáz körüli település viszonyait, legalább arra törekedtünk, hogy minden nagyobb fejlesztési régióból egy kisváros bekerüljön a kutatásunkba. A Dél-Alföldi régióban nem sikerült kisvárost választanunk, de Mezőtúr néhány kilométerre esik a régióhatártól.

A kisváros esettanulmányok a Társadalomtudományi Kutatóközpont Szociológiai Intézetében folytatott társadalmi integráció kutatás keretében készültek. A társadalmi integráció fogalmát, a kutatás elméleti alapjai szerint, nem célravezető a hátrányos helyzetben levő társadalmi rétegek, csoportok inklúziójának a témakörére szűkíteni (Dupcsik - Szabari 2015; Szabari 2015). A társadalmi integráció az egyén vagy intézmény együttműködése egy csoporttal vagy annál nagyobb valóságos vagy szimbolikus közösséggel, amelynek alapja az átlátható és legitim értékek részleges elfogadása és követése. Az integrációt, az egyének, intézmények, és kapcsolatok szintjein is megvalósuló társadalmi újratermelés folyamatosságának feltételét (Ferge 1990) viszonylag állandó mechanizmusok tartják fenn, amelyek megismerhetők a tudományos kutatás számára, és amelyekben az együttműködési készség, a kodifikált szerződések vagy szóbeli megállapodások, a normák és az értékek, valamint a társadalmat öszszetartó, a társadalmi szereplők együttműködését kiváltó és motiváló, vagy azzal ellentétben ható, kiszámítható jelenségek, szerkezetek és rendszerek, intézményesített vagy perszonális kényszerek kapnak meghatározó szerepet. Az adott mechanizmus résztvevőinek tudása és képzetei az integráció sikerességének, vagy azok hiányosságai és egyenlőtlen elosztása a dezintegráltságának lényeges meghatározóivá válhatnak. További alapfogalmak voltak a kutatás számára az integrációs dimenziók és az integrátorok, az integráció irányítói, befolyásolói és szervezői. Az integrációs dimenzió az integrált, tehát együttműködésre ösztönzött, manipulatív úton vagy nyílt kommunikációban rávett, esetleg az erőszak különféle módozataival rákényszerített közösségek életének, társadalmi újratermelésének az a területe, amelyben a legfontosabb integrációs mechanizmusok müködnek.

A kisvárosok kutatásának az volt a kihívása, hogy megtaláljuk azt, vagy azokat az integrációs dimenziókat, amelyben az egyes helyi közösségek együttműködése vagy éppen szembenállása szerveződik. Azonosítsuk azokat a politikai, szociális és kulturális mechanizmusokat, értékeket és normákat, amelyek az integrációt fenntartják vagy éppen megakadályozzák, megtaláljuk és leírjuk azoknak a tevékenységi és társadalmi jellemzőit, akik az integráció irányitói és szervezői. A folyóirat ebben a számában közölt esettanulmányok semmiképp sem tekinthetők hagyományos értelemben vett kisvároskutatás eredményeinek, mert egyetlen, bár az adott település társadalmi minősége szempontjából meghatározó témára, az integrációra irányulnak.

Korábbi munkákból (Gerő - Szabó 2017, 2019; Csurgó - Kovách 2018) tudjuk, hogy a magyar társadalom elsősorban politikailag integrált, és ezt a tételt a hét kisváros példái sem ellentételezik. A politikailag vezérelt integráció és dezintegráció azonban nem jelenti az integráció egydimenziósságát. Zalaszentgróton a gazdaság és a civil szerveződések, Marcaliban a centralizáló politika és kultúragazdaság, Kisvárdán a politikailag szervezett gazdaság, kultúra és sport, Gyöngyösön a redisztribúció és a civil világ kettősége, Zsámbékon a lokális helyi (kisebbségi) identitás, Móron leginkább a gazdaság és a társadalompolitika, Mezőtúron a hagyományok és értékek adják a politikának alávetett, illetve az attól néhol többé-kevésbé függetlenedni képes, legfontosabb integrációs dimenziót. Az integráció helyi föszereplőiről az esettanulmányok is visszagazolják, hogy gazdaságilag megerősödő, a teljes magyar társadalom felső-középrétegeitől értékeit és kulturális orientáltságát tekintve lassan talán eltávolodó, de nem feltétlenül és nem hierarchikusan alárendelődő, kultúra-fogyasztásban sem lemaradó, újonnan erőre kapó és társadalmi helyzetét, integrációs kapacitásait manifesztálni képes társadalmi réteg, osztály formálódott. Hogy mindezt legalább részleteiben egyfajta polgárosodásnak foghatjuk-e fel, annak megválaszolásához további kutatásokra, elemzésekre lesz szükség. 


\section{Felhasznált irodalom}

Gerő Márton - Hajdu Gábor - Kovách Imre Kristóf Luca - Szabó Andrea 20204 év múlva. A magyar társadalom integráltsága - megjelenés alatt

Albert Fruzsina - Dávid Bea - Kmetty Zoltán - Kristóf Luca - Róbert Péter - Szabó Andrea 2017 Mapping the Post-communist Class Structure: Findings from a New Multidimensional Hungarian Class Survey East European Politics and Society 31:544-565. https://doi.org/10.1177/0888325417739954

Csurgó Bernadett - Kovách Imre 2018 A szegénység elleni projektek haszna: A kisvárosi szociális földprogram példája. Magyar Tudomány (179) 6:902-911. https://doi. org/10.1556/2065.179.2018.6.17

Dupcsik Csaba - Szabari Vera 2015 Elméleti bevezető az Integrációs és dezintegrációs folyamatok a magyar társadalomban címü OTKA kutatáshoz. Socio.hu Társadalomtudományi Szemle, 3:33-43.

Ferge Zsuzsa 1990 Variációk a társadalmi integráció témájára. Esély, 1:3-17.

Gerő Márton - Szabó Andrea 2017 A társadalom politikai integrációja. A politikai értékcsoportok. In Kovách Imre szerk. Társadalmi integráció. Az egyenlötlenségek, az együttmüködés, az újraelosztás és a hatalom szerkezete a magyar társadalomban. Budapest, Szeged, Belvedere Meridionale - MTA TK Szociológiai Intézet, 117-154.
Kovách Imre - Hajdu Gábor - Gerő Márton Kristóf Luca - Szabó Andrea 2016 A magyar társadalom integrációs és rétegződésmodelljei. Szociológiai Szemle, 26 (3):4-27.

Kovách Imre - Hajdu Gábor - Gerő Márton Kristóf Luca - Szabó Andrea 2017 Az integrációs modell. In Kovách Imre szerk. Társadalmi integráció. Az egyenlötlenségek, az együttmüködés, az újraelosztás és a hatalom szerkezete a magyar társadalomban. Budapest, Szeged, Belvedere Meridionale - MTA TK Szociológiai Intézet, 21-47.

Pirisi Gábor - Trócsányi András 2009. Így készül a magyar város. Területi Statisztika 12 (2):137-147.

Pirisi Gábor 2009 Város vagy nem város? Dilemmák a formális és a funkcionális városfogalom kettőssége kapcsán. Területi Statisztika 12 (2):129-136.

Savage, M. - Devine, F. - Cunningham, N. Taylor, M. - Li, Y. - Hjellbrekke, J. - Le Roux, B. - Friedman, S. - Miles A. 2013 A new model of social class: Findings from the BBC's great british class survey experiment. Sociology, 2:219-250. https://doi. org/10.1177/0038038513481128

Szabari Vera 2015 A normák mint integrációs mechanizmusok a mai magyar társadalomban. Socio.hu Társadalomtudományi Szemle, 3:1-16. 